Ekspose volume 16, Nomor 1, Januari - Juni 2017

P-ISSN: 1412-2715, E-ISSN: 2616-4412

\title{
IMPLIKASI PENERAPAN PERATURAN MAHKAMAH AGUNG NO. 1 TAHUN 2016 TENTANG PROSEDUR MEDIASI DI PENGADILAN TERHADAP CAPAIAN ASAS FLEKSIBILITAS (Studi Kasus pada Pengadilan Agama Kelas 1 B Watampone)
}

\author{
Jamaluddin $\mathbf{T}$. \\ Dosen Sekolah Tinggi Agama Islam Negeri Watampone \\ jamaluddint@gmail.com
}

\begin{abstract}
One of the civil event principle of justice is flexibility ground as contained in Section 2 ( 4) Law Number 48 Year 2009 about Judicial Power that jurisdiction conductedplainly, quickly, and light expense. Tone with Perma RI Number konsideran 1 Year 2016 about procedure of mediasi in Justice. Base Flexibility represent expectation all party, specially to is drawee of divorce dispute in Justice Of Religion. PERMA Number 1 Year 2016 representing Appellate Court effort in integrating mediasi into process attend legal procedure in Justice, where expected can overcome the problem of heaping of case, and also strengthen and maximize function institute justice in solving of dispute. Beside that, process mediasi become to increase because there are section $130 \mathrm{HIR}$ and 154 RBG obliging mediasi each early conference, and ifdo not be executed to cause conference of cancelation for the shake of law. Even farther that mediasi can be executed till decision of inkracht. But that way direct ekses of the PERMA is its time become length (old), expense increase, and entangle mediator with all is protocol of him so that make process attend legal procedure do not modestly (complicated).

This Research represent research of field (Field of Research) having the character of qualitative [in] area punish by using approach of yuridis, that is using science theory punish in explaining implication applying of Regulation of Appellate Court of RI to flexibility ground performance at dispute divorce in Justice of Religion Class 1 B Watampone.
\end{abstract}

Keywords: Mediasi (nonlitigasi) dan Upaya Damai (Litigasi), Asas Fleksibilitas

\section{Pendahuluan}

Manusia adalah makhluk sosial (zoon politicon) karena mereka saling membutuhkan. Dengan adanya hubungan yang saling membutuhkan tersebut, maka sering terjadi fenomena sosial berupa sengketa yang timbul akibat adanya kepentingan yang berbeda, kesalahpahaman, wanprestasi dan sebagainya. Bila dalam 
Ekspose volume 16, Nomor 1, Januari - Juni 2017

P-ISSN: 1412-2715, E-ISSN: 2616-4412

hubungan sosial tersebut terjadi sengketa, maka peranan hukum menjadi penting dalam menyelesaikan sengketa tersebut.

Salah satu asas hukum acara perdata adalah asas fleksibilitas sebagaimana tercantum dalam Pasal 2 angka 4 Undang-Undang Nomor 48 Tahun 2009 tentang Kekuasaan Kehakiman bahwa peradilan dilakukan dengan sederhana, cepat, dan biaya ringan. Hal senada dengan konsideran Perma RI Nomor 1 tahun 2008 jo Perma Nomor 1 Tahun 2016 tentang prosedur mediasi di Pengadilan. Asas fleksibilitas merupakan harapan semua pihak, khususnya bagi yang tersangkut sengketa perceraian di Pengadilan.Menjawab tantangan zaman dan harapan masyarakat tersebut, Mahkamah Agung RI meresponnya melalui PERMA tersebut.

Pada dasarnya penerapan Pasal 4 PERMA Nomor 1 Tahun 2008 merupakan upaya dalam mengintegrasikan mediasi ke dalam proses beracara di Pengadilan, diharapkan dapat mengatasi masalah penumpukan perkara, serta memperkuat dan memaksimalkan fungsi lembaga pengadilan dalam penyelesaian sengketa.

Harapan tersebut mungkin efektif pada sengketa perdata, tidak pada perkara perceraian. Penerapan PERMA nomor 1 Tahun 2016 yang nampak pertama di permukaan adalah bertentangan dengan asas fleksibilitas karena waktunya menjadi panjang (lama), biaya bertambah (biaya proses mediasi), dan melibatkan mediator dengan segala protokolernya sehingga menjadikan proses beracara tidak sederhana (rumit dan ribet).

Proses mediasi (upaya damai) sebelum diberlakukannya PERMA Nomor 1 Tahun 2016 ini, sebenarnya sudah ada, namun dilaksanakan pada setiap awal persidangan sebagaimana amanah dari pasal 130 HIR dan 154 RBG. Tidak terlaksananya upaya damai pada setiap awal persidangan ini mengakibatkan persidangan batal demi hukum. Dengan adanya Perma Nomor 1 Tahun 2016 tersebut menjadikan waktu dan ruang mediasi bertambah (mediasi litigasi dan non litigasi). Mediasi Litigasi adalah mediasi yang dilaksanakan dalam persidangan oleh Majelis Hakim yang menyidangkan perkara yang bersangkutan, sedangkan Mediasi Non Litigasi adalah mediasi yang dilaksanakan di luar persidangan, yang oleh PERMA disebutkan sebagai mediasi yang terintegrasi dengan proses beracara di Pengadilan. Dengan kata lain bahwa pelanggaran atas asas fleksibilitas sudah pasti, di samping keberhasilan mediasi belum pasti pula.

Disamping proses mediasi non litigasi, mediasi dalam litigasi terus dilaksanakan di peradilan tingkat pertama, dan bahkan dibuka peluang berdamai sampai putusan mempunyai kekuatan hukum tetap (BHT), yaitu bisa sampai pada upaya hukum terakhir (tingkat kasasi di Mahkamah Agung). Hal itu menunjukkan 
Ekspose volume 16, Nomor 1, Januari - Juni 2017

P-ISSN: 1412-2715, E-ISSN: 2616-4412

bahwa betapa banyaknya ruang dan waktu yang telah diberikan kepada para pihak yang bersengketa untuk melakukan mediasi (diluar PERMA).

Dari Latar belakang tersebut, maka penulis merumuskan judul "Implikasi Penerapan Peraturan Mahkamah Agung Nomor 1 Tahun 2016 tentang Prosedur Mediasi di Pengadilan terhadap Capaian Asas Fleksibilitas pada Sengketa Cerai (Studi Kasus Pengadilan Agama Kelas 1 B Watampone)

Berdasarkan uraian latar belakang di atas, yang menjadi permasalahan adalah sebagai berikut: (1) Bagaimana tingkat keberhasilan penerapan PERMA No. 1 Tahun 2016 di Pengadilan Agama Kelas 1 B Watampone pada sengketa cerai ? (2) Bagaimana implikasi penerapan PERMA No. 1 Tahun 2016 di Pengadilan Agama Kelas 1 B Watampone dalam mewujudkan asas fleksibilitas pada sengketa cerai ?

Penelitian ini merupakan penelitian lapangan (Field Research) yang bersifat kualitatif di bidang hukum dengan menggunakan pendekatan yuridis, yaitu menggunakan teori ilmu hukum dalam menjelaskan implikasi penerapan Peraturan Mahkamah Agung RI terhadap capaian asas fleksibilitas pada sengketa cerai di Pengadilan Agama Kelas 1 B Watampone.

Penelitian ini menggunakan data primer dan data sekunder. Data primer adalah data empiris yang diperoleh dari penelitian lapangan (Field Research), dengan cara observasi dan wawancara.

Adapun data sekunder yang dimaksud adalah data kepustakaan (Library research), yaitu pengumpulan data yang dilakukan dengan cara menelaah berbagai referensi, seperti hasil penelitian, buku-buku dan karya ilmiah, serta peraturan perundang-undangan yang relefan dengan penelitian ini.

Data sekunder pada penelitian ini dapat dibedakan sebagai berikut :

a. Bahan hukum primer, terdiri atas Undang-Undang Nomor 48 Tahun 2009 tentang Kekuasaan Kehakiman; Undang-Undang Nomor 7 Tahun 1989 Tentang Peradilan Agama. Undang-Undang Nomor 3 Tahun 2006; PERMA Nomor 1 Tahun 2008 yang telah diperbaharui dengan PERMA Nomor 1 Tahun 2016 tentang Prosedur Mediasi di Pengadilan,

b. Bahan Hukum Sekunder, yakni bahan yang memberikan penjelasan mengenai bahan hukum primer, seperti hasil penelitian dan pendapat para pakar hukum tentang mediasi atau yang serupa dengan upaya damai lainnya.

c. Bahan Hukum Tersier, yakni bahan yang memberikan penjelasan terhadap bahan hukum primer dan bahan hukum sekunder, seperti kamus hukum. ${ }^{1}$

${ }^{1}$ S. Nasution, Metode Research(Penelitian Ilmiah), (Jakarta : PT. Bumi Aksara, 2003), h. 31- 
Ekspose volume 16, Nomor 1, Januari - Juni 2017

Tahapan-tahapan penelitian adalah pertama-tama menelaah semua catatan hasil wawancara, berkas-berkas dokumentasi, dan membandingkan dengan data-data yang diperoleh dari penelitian kepustakaan, khususnya yang berupa peraturan perundang-undangan. Kemudian dilakukan editing dan membuang data yang tidak relevan dengan penelitian. Analisis data dilanjutkan dengan mengadakan pemeriksaan keabsahan data, menafsirkan data, menguji data dengan teori yang telah dipilih, dan akhirnya diadakan penulisan hasil penelitian dengan bentuk deskritif kualitatif, yaitu data-data yang terkumpul akan diuraikan dalam bentuk pemaparan kalimat sesuai dengan rumusan masalah penelitian ini.

Sebagai penelitian hukum yang bersandar pada peraturan perundangundangan dan penerapannya di Pengadilan Agama Watampone, bentuk analisis yang dipilih adalah deskriptif kualitatif. Apabila dilihat dari tujuan penelitian yang akan dilakukan, penelitian ini dapat dikategorikan sebagai penelitian deskriptif karena diharapkan dapat memberikan gambaran tentang suatu gejala atau hasil penerapan aturan perundang-undangan. Penelitian deskriptif juga mendeskripsikan suatu masalah yang bersifat kasuistik dengan cara menggambarkan kasus yang sedang diteliti, berdasarkan hubungan antara teori dengan kenyataan di lapangan. Penelitian deksriptif lebih spesifik dengan memusatkan perhatian pada aspek-aspek tertentu dan sering menunjukkan hubungan antara variabel. ${ }^{2}$

Tujuan yang ingin dicapai dalam penelitian ini adalah sebagai berikut: (1) Untuk mengetahui tingkat keberhasilan penerapan PERMA No. 1 Tahun 2016 di Pengadilan Agama Kelas 1B Watampone pada sengketa cerai. (2) Untuk mengetahui implikasi penerapan PERMA No. 1 Tahun 2016 di Pengadilan Agama Kelas 1B Watampone dalam mewujudkan asas fleksibilitas pada sengketa cerai.

a. Kegunaan Penelitian

Dengan diketahui dan ditemukannya tingkat keberhasilan penerapan

Peraturan Mahkamah Agung RI Nomor 1 Tahun 2016 tentang prosedur mediasi di pengadilan terhadap sengketa cerai, maka dapat :

- Memberikan masukan dalam rangka lebih meningkatkan dan menseriusi pelaksanaan mediasi agar mediasi bisa berhasil.

- Menjadi sumbangsih bagi pengembangan ilmu mediasi.

- Memberikan masukan kepada para pihak terkait, terkhusus pada Mahkamah Agung RI, agar mempertimbangkan perkara sengketa cerai, dan diharapkan agar dimasukkan ke dalam kelompok perkara yang tidak dimediasi, karena telah diteliti oleh banyak peneliti di berbagai

${ }^{2}$ Ibid. h. 24. 
Ekspose volume 16, Nomor 1, Januari - Juni 2017

P-ISSN: 1412-2715, E-ISSN: 2616-4412

tempat/pengadilan agama yang berbeda yang hasilnya sangat jauh dari harapan.

\section{Pembahasan}

Mahkamah Agung Republik Indonesia mewajibkan para pihak menempuh mediasi sebelum perkara diputus oleh hakim melalui Peraturan Mahkamah Agung (Perma), didasari atas beberapa alasan, yaitu ${ }^{3}$ :

1. Proses mediasi diharapkan dapat mengatasi masalah penumpukan perkara.

2. Proses mediasi dipandang sebagai cara penyelesaian sengketa yang lebih cepat dan murah dibandingkan dengan proses litigasi.

3. Pemberlakuan mediasi diharapkan dapat memperluas akses bagi para pihak untuk memperoleh rasa keadilan.

4. Institusionalisasi proses mediasi ke dalam sistem peradilan dapat memaksimalkan fungsi lembaga pengadilan dalam menyelesaikan sengketa.

5. Trend penyelesaian hukum di berbagai negara di dunia.

Landasan yuridis mediasi sebagai berikut: HIR pasal 130 (Pasal 154 RBg., Pasal $31 \mathrm{Rv}$ ). Dalam pasal 130 ayat (2) HIR dikemukakan pula bahwa jika perdamaian dapat dicapai, maka saat itu pula dibuat putusan perdamaian dengan menghukum para pihak untuk mematuhi persetujuan damai yang telah mereka buat. Putusan perdamaian itu berkekuatan hukum tetap dan dapat dijalankan sebagaimana putusan biasa. Putusan perdamaian dapat dibatalkan jika dalam perjanjian perdamaian itu, terjadi kekhilafan mengenai orangnya, atau mengenai pokok perselisihan, atau juga karena adanya penipuan atau paksaan dalam membuatnya.

Pasal 39 ayat 1 Undang-Undang Nomor 1 Tahun 1974 tentang Perkawinan dan Pasal 65 Undang-Undang Nomor 7 Tahun 1989 tentang Peradilan Agama, danPasal 115 Kompilasi Hukum Islam. Perceraian hanya dapat dilakukan di depan sidang Pengadilan setelah Pengadilan yang bersangkutan berusaha dan tidak berhasil mendamaikan kedua belah pihak.

Pasal 32 PP No.9 Tahun 1975, danPasal 144 Kompilasi Hukum Islam. Apabila tercapai perdamaian, maka tidak dapat diajukan gugatan perceraian baru

${ }^{3}$ Anonimous. Buku Komentar Peraturan Mahkamah Agung RI No. 01 Tahun 2008 tentang Pelaksanaan Mediasi di Pengadilan. Dibuat atas kerjasama MARI, Japan International Cooperation Agency (JICA) dan Indonesia Institute for Conflict Transformation (IICT), 2008, h. 7-12 
Ekspose volume 16, Nomor 1, Januari - Juni 2017

P-ISSN: 1412-2715, E-ISSN: 2616-4412

berdasarkan alasan atau alasan-alasan yang ada sebelum perdamaian dan telah diketahui oleh penggugat pada waktu dicapainya perdamaian.

Pasal 131 (2) Kompilasi Hukum Islam. Setelah Pengadilan Agama tidak berhasil menashati kedua belah pihak dan ternyata cukup alasan untuk menjatuhkan talak serta yang bersangkutan tidak mungkin lagi hidup rukun dalam rumah tangga, pengadilan Agama menjatuhkan keputusannya tentang izin bagi suami untuk mengikrarkan talak.

Pasal 143 (1-2) Kompilasi Hukum Islam:

a. Dalam pemeriksaan gugatan perceraian Hakim berusaha mendamaikan kedua belah pihak.

b. Selama perkara belum diputuskan usaha mendamaikan dapat dilakukan pada setiap sidang pemeriksaan.

\section{KeadaanPerkara di Pengadilan Agama Kelas 1 B Watampone}

Pengadilan Agama Watampone memiliki wilayah yurisdisi meliputi seluruh wilayah Kabupaten Bone yang terdiri dari 27 Kecamatan.

Tabel 5

Keadaan Perkara Gugatan dan Permohonan

Yang Diterima oleh Pengadilan Agama Watampone

Sejak Tahun 2012 s/d Juli $2016^{4}$

\begin{tabular}{|c|c|c|c|c|}
\hline No. & TAHUN & $\begin{array}{c}\text { PERKARA } \\
\text { GUGATAN }\end{array}$ & $\begin{array}{c}\text { PERKARA } \\
\text { PERMOHONAN }\end{array}$ & JUMLAH \\
\hline 1. & 2012 & 1.241 & 231 & 1.472 \\
2. & 2013 & 1.230 & 596 & 1.826 \\
3. & 2014 & 1.401 & 1.132 & 2.533 \\
4. & 2015 & 1.371 & 1.207 & 2.578 \\
5. & 2016 & 713 & 889 & 1.602 \\
& & Januari - Juli & Januari-Juli & Januari - Juli \\
\hline & JUMLAH & $\mathbf{5 . 9 5 6}$ & $\mathbf{4 . 0 5 5}$ & $\mathbf{1 0 . 0 1 1}$ \\
\hline
\end{tabular}

Dari tabel 5 di atas, dipahami bahwa perkara di Pengadilan Agama Watampone, baik kontensius maupun volunter setiap tahun mengalami peningkatan.

${ }^{4}$ Sumber: Data KepaniteraanPengadilan Agama Kelas 1 B Watampone Tahun 2016 
Ekspose volume 16, Nomor 1, Januari - Juni 2017

P-ISSN: 1412-2715, E-ISSN: 2616-4412

Hal tersebut menunjukkan bahwa apa yang disebutkan oleh Perma No. 1 Tahun 2016 mengenai penumpukan berkas perkara, benar. Oleh karena itu, niat baik seluruh stakeholder Mahkamah Agung RI melalui Perma No. 1 Tahun 2016 tentang prosedur mediasi di Pengadilan memang suatu yang nyata dan patut diindahkan dan ditindaklanjuti oleh seluruh lembaga peradilan yang ada di bawahnya, termasuk di antaranya Pengadilan Agama.

Sesuai dengan batasan masalah penelitian ini, maka peneliti hanya meneliti dan menampilkan perkara yang dapat dimediasi di Pengadilan Agama Watampone, yaitu perkara perceraian.

Tabel 6

Keadaan Perkara Gugatan Cerai (Cerai Gugat dan Cerai Talak) Yang Diterima oleh Pengadilan Agama Watampone Sejak Tahun 2012 s/d Juli 2016

\begin{tabular}{|c|c|c|c|c|}
\hline No. & TAHUN & $\begin{array}{c}\text { CERAI } \\
\text { GUGAT }\end{array}$ & $\begin{array}{c}\text { CERAI } \\
\text { TALAK }\end{array}$ & JUMLAH \\
\hline 1. & 2012 & 906 & 323 & 1.229 \\
2. & 2013 & 837 & 226 & 1.063 \\
3. & 2014 & 1.097 & 274 & 1.371 \\
4. & 2015 & 1.047 & 297 & 1.344 \\
5. & 2016 & 528 & 175 & 703 \\
& & Januari - Juli & Januari - Juli & Januari - Juli \\
\hline & JUMLAH & $\mathbf{4 . 4 1 5}$ & $\mathbf{1 . 2 9 5}$ & $\mathbf{5 . 7 1 0}$ \\
\hline
\end{tabular}

Dari tabel 6 tersebut di atas terlihat bahwa ada 5.710 (lima ribu tujuh ratus sepuluh) perkara kontensius yang diterima sejak tahun 2012 sampai dengan tahun 2016, menggambarkan bahwa setiap tahunnya lebih dari 1.000 (seribu) perkara perceraian yang diterima, diperiksa, diadili dan diputus di Pengadilan Agama Watampone.

Keberhasilan Penerapan Peraturan Mahkamah Agung RI Nomor 1 Tahun 2016 di Pengadilan Agama Kelas 1 B Watampone pada Sengketa Cerai.

Perceraian menurut bahasa Indonesia berarti "pisah" dari kata dasar "cerai", sedangkan dalam bahasa Arabnya berasal dari kata "thalaq" yang berarti

${ }^{5}$ Sumber: Data TerakhirKepaniteraanPengadilan Agama Kelas 1 B Watampone Tahun 2016 
Ekspose volume 16, Nomor 1, Januari - Juni 2017

"melepaskan" dan "meninggalkan"6. Menurut istilah (syara') perceraian adalah melepaskan ikatan perkawinan. Sebutan tersebut adalah lafadz yang sudah dipergunakan pada masa jahiliyah yang kemudian digunakan oleh syara ${ }^{\text {,7 }}$. Perceraian dalam istilah ahli figh disebut talak atau furqoh, adapun arti dari talak ialah membuka ikatan.

Rumitnya persoalan perceraian tersebut setidaknya terlihat dari beberapa segi, antara lain: Pertama, perceraian sesungguhnya adalah puncak dari kumulasi persoalan yang tidak terselesaikan dengan baik, sehingga mengendap dalam alam bawah sadar akhirnya menjadi parah masalah hubungan suami isteri. Kedua, tahapan-tahapan terjadinya perceraian dalam kehidupan seseorang, sebagai berikut: ${ }^{8}$

1. Perceraian hati (emotional divorce), ditandai dengan perasaan terluka, marah, hilangnya ketertarikan dan kepercayaan;

2. Perceraian hukum (legal divorce), yang menciptakan kebolehan untuk menikah lagi;

3. Perceraian ekonomi (economic divorce), menandai penataan ulang pengaturan keuangan dan kekayaan;

4. Perceraian pengasuhan bersama (co-parenting divorce), yang melibatkan persoalan-persoalan tempat tinggal dan hubungan dengan anak. Hal ini seringkali menimbulkan akibat yang paling lama diantara orang-orang yang bercerai;

5. Perceraian fisik (phisic divorce), menggambarkan sarana-sarana dimana otonomi individu itu dipulihkan. Perceraian ini dipandang sebagai bagian yang paling sulit meskipun merupakan prestasi yang paling konstruktif diantara semuanya;

Berdasarkan kompetensi Pengadilan Agama,disampingperkara contensius (Gugatan), jugamengadiliperkara voluntair (Permohonan). Adapun yang dapat dimediasi menurut PERMA tersebut adalah perkara yang masuk kategori contensius atau gugatan.

Tabel 7

\section{Data Pelaksanaan Mediasi Di Pengadilan Agama Watampone}

\footnotetext{
${ }^{6}$ Abu Kamal Malik Sbin as-Sayyid, Shahih Fikih Sunnah, (Jakarta: Pustaka Azzam, 2007), h. 361 .

${ }^{7}$ Imam Taqiyuddin Abu Bakar bin Muhammad Al-Husaini, Kifayatul Akhyar, (Surabaya: Bina Iman, 1993), Juz 11, h. 175

${ }^{8}$ Marian Roberts, Mediation in Family Disputes: Principles and Practice (Third Edition), (Hampshire: Ashgate Publishing Ltd, 2008), h. 30
} 
Ekspose volume 16, Nomor 1, Januari - Juni 2017

P-ISSN: 1412-2715, E-ISSN: 2616-4412

Tahun $2012-20169$

\begin{tabular}{|l|c|c|c|c|c|c|c|}
\hline No & Tahun & $\begin{array}{c}\text { Jumlah } \\
\text { Perkara } \\
\text { Gugatan }\end{array}$ & $\begin{array}{c}\text { Perkara } \\
\text { yang } \\
\text { Dimediasi }\end{array}$ & $\begin{array}{c}\text { Berhasil } \\
\text { Dimediasi }\end{array}$ & $\begin{array}{c}\text { Gagal } \\
\text { Dimediasi }\end{array}$ & $\begin{array}{c}\text { Tidak } \\
\text { Layak }\end{array}$ & Ket. \\
\hline 1. & 2012 & 1.241 & 144 & 1 & 116 & 27 & \\
\hline 2. & 2013 & 1.230 & 153 & 8 & 118 & 27 & \\
\hline 3. & 2014 & 1.401 & 156 & 8 & 148 & & \\
\hline 4. & 2015 & 1.371 & 173 & 6 & 140 & 27 & \\
\hline 5. & 2016 & $\begin{array}{c}713 \\
\text { Jan-Juli } 2016\end{array}$ & 70 & 2 & 45 & 23 & \\
\hline \multicolumn{2}{|r|}{ Jumlah } & 5.956 & 696 & 25 & 567 & 104 & \\
\hline
\end{tabular}

(Data Kepaniteraan PA Kelas 1 b Watampone pada bulan Agustus 2016)

Jumlah perkara kontensius 5.956 perkara, yang dapat dimediasi $696(11,7 \%)$, dan yang berhasil dimediasi hanyalah 3,6\%. Berdasarkan keterangan dari beberapa mediator bahwa dari 3,6\% tersebut kebanyakan perkara sengketa harta (harta bersama, nafkah, dan waris), adapun masalah perceraian hanya berkisar $1 \%$ saja yang berhasil. $^{10}$

Hal tersebut menunjukkan ribuan perkara kontensius pertahun sementara yang dapat dimediasi hanya berkisar 11\%, padahal berdasarkan pasal 2 (1), pasal 4 dan pasal 17 (1) bahwa semua perkara yang masuk kategori gugatan dalam lingkungan peradilan agama wajib menempuh proses mediasi. Banyak perkara gugatan yang tidak dapat dimediasi di Pengadilan Agama Watampone karena berbagai alasan, di antaranya adalah:

1. Salah satu pihak tidak hadir pada sidang pertama (Verstek)

Bila tergugat tidak hadir pada sidang pertama, maka sidang ditunda untuk memanggil kembali tergugat, kalau tergugat datang pada sidang kedua maka sidang ditunda untuk mediasi, dan pelaksanaan mediasinya diupayakan langsung dilaksanakan pada hari itu juga dan mediasi kedua dilaksanakan pada hari sidang ketiga sebelum perkara disidangkan. Dua kali mediasi telah memenuhi standar minimal mediasi. Adapun bila tergugat tetap tidak hadir pada sidang kedua meskipun telah dipanggil secara sah dan patut, maka

\footnotetext{
${ }^{9}$ Sumber: Data TerakhirKepaniteraanPengadilan Agama Kelas 1 B Watampone Tahun 2016

${ }^{10}$ Drs. H. Kamaluddin dkk.Hakim Pengadilan Agama Watampone, Wawancara oleh peneliti di Pengadilan Agama Watampone,15Agustus 2016.
} 
Ekspose volume 16, Nomor 1, Januari - Juni 2017

mediasi tidak dilaksanakan, dan agenda sidang langsung pembacaan gugatan, dan bahkan bila memungkinkan langsung pembuktian dan bahkan bisa putus hari itu juga. Dengan demikian pelaksanaan acara menjadi mudah, murah dan cepat. ${ }^{11}$

2. Perkara Gaib

Bila kondisi suatu perkara masuk dalam kategori gaib atau tidak diketahui tempat tinggalnya secara pasti menyebabkan sebuah perkara kontensius yang mestinya dimediasi menjadi tidak dimediasi. Namun demikian terkadang juga ada yang dimediasi bila kebetulan tergugat datang ke pengadilan mengikuti persidangan. ${ }^{12}$

3. Tergugat lebih dari seorang

Tergugat lebih dari seorang sering terjadi pada perkara waris. Dua orang mediator menyebutkan bahwa pada hari terjadinya mediasi seringkali salah satu tergugat tidak hadir, sehingga mediasi tidak dapat dilaksanakan, dan di dalam laporan Mediasi dianggap "tidak layak dimediasi". ${ }^{13}$

Oleh karena itu, mediasi di Pengadilan Agama Watampone masih sangat jauh dari harapan karena dari jumlah perkara gugatan yang masuk,sejakTahun 2012 sampai dengan Juli 2016 mencapai 5.956 perkara, hanya 11,7\% yang dapat dimediasi. Sedangkan yang berhasil dimediasi dimediasi tersebut hanya 3,6\%, sementara yang gagal mencapai $81,5 \%$, dan yang tidak layak adalah $14,9 \%$.

Setelah dipersentasekan data mediasi di Pengadilan Agama Watampone tersebut di atas menunjukkan bahwa apa yang diharapkan oleh Perma nomor 1 Tahun 2016 sebagaimana dalam konsiderannya, untuk mewujudkan asas fleksibilitas dan mengurangi penumpukan perkara, masih jauh dari harapan.

${ }^{11}$ Drs. H. Kamaluddin dkk.Hakim Pengadilan Agama Watampone, Wawancara oleh peneliti di Pengadilan Agama Watampone,15Agustus 2016.

12 Drs. H. Muh. Kasyim, M.H.Hakim Pengadilan Agama Watampone, Wawancara oleh peneliti di Jalan Yos Sudarso (Jalan Bajoe) Watampone,26September 2016.

${ }^{13}$ Drs. M. Yahya,Hakim Pengadilan Agama Watampone, Wawancara oleh peneliti di Jalan Husain Jeddawi Watampone,26September 2016. 
Ekspose volume 16, Nomor 1, Januari - Juni 2017

\section{Mewujudkan Asas Fleksibilitas pada Sengketa Cerai.}

Penerapan Perma pada dasarnya adalah pelaksanaan proses mediasi. Adapun proses dibagi ke dalam tiga tahap, yaitu tahap pramediasi, tahap pelaksanaan mediasi dan tahap akhir mediasi.

Pada tahap pra mediasi, mediator melakukan beberapa langkah antara lain, membangun kepercayaan diri, menghubungi para pihak,menggali dan memberikan informasi awal mediasi, fokus pada masa depan, mengkoordinasikan pihak bertikai, mewaspadai perbedaan budaya, menentukan siapa yang hadir, menentukan tujuan pertemuan, kesepakatan waktu dan tempat dan menciptakan rasa aman bagi kedua belah pihak untuk bertemu dan membicarakan perselisihan mereka. ${ }^{14}$

Tahap pelaksanaan mediasi adalah tahap di mana pihak-pihak yang bertikai sudah berhadapan satu sama lain dan memulai proses mediasi. Dalam tahap ini, terdapat beberapa langkah penting antaralain: sambutan pendahuluan mediator, presentasi dan pemaparan kisah para pihak, mengurutkan dan menjernihkan permasalahan,berdiskusi dan negosiasi masalah yang disepakati, menciptakan opsiopsi, menemukan butir kesepakatan dan merumuskan keputusan, mencatat dan menuturkan kembali keputusan dan penutup mediasi.

Tahap akhir hasil mediasi adalah tahap di mana para pihak menjalankan hasilhasil kesepakatan, yang tertuang suatu perjanjian tertulis.

Penerapan PERMA no. 1 Tahun 2016 tentang Prosedur Mediasi di Pengadilan Agama Watampone, peneliti membagi kepada dua bagian.

\section{Penerapan PERMA No. 1 Tahun 2016 di Pengadilan Agama Watampone}

Beberapa teknis penerapan PERMA yang diterapkan di Pengadilan Agama Watampone.

a. Penunjukan langsung mediator ${ }^{15}$

Pada sidang pertama, setiap perkara kontensius wajib dilakukan mediasi sebelum perkaranya diperiksa. Dan setiap Hakim, Mediator, Para Pihak dan/atau kuasa hukum wajib mengikuti prosedur penyelesaian sengketa melalui Mediasi (pasal 3 ayat 1). Berasarkan pasal 19 ayat 1 PERMA No. 1 Tahun 2016 bahwa para pihak berhak memilih mediator yang ada di papan mediator,

\footnotetext{
${ }^{14}$ Ronal S. Kraybill, Alice Frazer Evans dan Robert A. Evans, Peace Skill, Panduan Mediator terampil Membangun Perdamaian. (Yogyakarta: Penerbit Kanisius, 2006). h. 63-67.

${ }^{15}$ Drs. M. Yahya,Hakim Pengadilan Agama Watampone, Wawancara oleh peneliti di Jalan Husain Jeddawi Watampone, 26September 2016.
} 
Ekspose volume 16, Nomor 1, Januari - Juni 2017

namun karena banyaknya beban pekerjaan setiap mediator, maka di Pengadilan Agama Watampone dilakukan penunjukan langsung mediator artinya mediator tidak lagi dipilih oleh para pihak. Adapun pertimbangannya adalah sebagai berikut :

1. Agar tidak ada hakim yang notabene mediator yang mempunyai beban berlebih dari yang lain. Karena bila mediator dipilih, maka bisa terjadi ada hakim yang berlebihan bebannya ada pula yang tidak.

2. Pada umumnya para pihak belum mengenal, apalagi mengetahui tingkat kecerdasan para mediator yang ada di papan mediator.

Pada dasarnya menurut PERMA No. 1 Tahun 2016 pada Bagian Ketiga "Hak-hak Para Pihak Memilih Mediator" pasal 19, bahwa penunjukan atau pemilihan mediator dilakukan oleh para pihak (penggugat dan tergugat). Dengan demikian cara yang dipraktekkan di Pengadilan Agama Watampone bertentangan dengan PERMA.

b. Pemanggilan kedua terhadap tergugat, apabila tergugat tidak hadir pada siding pertama, sebagai pernghormatan, dan agar hak-hak tertugat terlindungi. ${ }^{16}$

c. Itikad Baik dan Sanksi

Penerapan Pasal 7 ayat 1 dan 2 pada sengketa cerai belum terlaksana di Pengadilan Agama Watampone, karena belum pernah ada penggugat yang melanggar pasal tersebut, umumnya tergugat yang tidak pernah hadir (verstek), dan pembebanan pembayaran biaya mediasi tidak pernah dilaksanakan oleh tergugat karena tergugat tidak pernah hadir, penggugat pun tidak keberatan membayarnya. ${ }^{17}$

\section{Penerapan PERMA No. 1 Tahun 2016 oleh Mediator}

a. Kaukus

Menurut para mediator di Pengadilan Agama Watampone, bahwa apabila penggugat dan tergugat saat dimediasi, mereka bertengkar terus dan tidak ada yang mengalah, mediator menempuh cara kaukus (mediasi terpisah), yaitu memanggil dahulu penggugat masuk ke ruang mediasi, setelah penggugat lalu dipanggil lagi tergugat atau sebaliknya, dan bila upaya kaukus pun tidak bisa, maka dinyatakan

16 Drs. H. Muh. Kasyim, M.H.Hakim Pengadilan Agama Watampone, Wawancara oleh peneliti di Jalan Yos Sudarso (Jalan Bajoe) Watampone,26September 2016.

${ }^{17}$ Drs. M. Yahya,Hakim Pengadilan Agama Watampone, Wawancara oleh peneliti di Jalan Husain Jeddawi Watampone, 26September 2016. 
Ekspose volume 16, Nomor 1, Januari - Juni 2017

tidak layak dimediasi. ${ }^{18}$ Mediasi dengan cara kaukus ini seringkali digunakan agar lebih efektif dan efisien, namun tetap dibatasi, karena dikhawatirkan terjadi fitnah, karena yang ada di dalam ruangan hanya mediator dengan salah satu pihak yang bersengketa. $^{19}$

b. Mediation Skills

Mediation Skills merupakan salah model penyelesaian sengketa yang effektif dan banyak berhasil. Dari beberapa pernyataan hakim, pada umumnya mengatakan bahwa keberhasilan mediator dalam melakukan upaya damai sangat dipengaruhi oleh kemampuan dan pengetahuan (skill) seorang mediator.

\section{Simpulan}

Pelaksanaan Peraturan Mahkamah Agung RI Nomor 1 Tahun 2016 di Pengadilan Agama Watampone telah berjalan sesuai hukum acara. Namun tingkat keberhasilannya masih sangat jauh dari yang diharapkan karena dari 5.956 perkara contensius hanya 25 yang berhasil dimediasi artinya keberhasilannya baru mencapai $0,4 \%$.

Penerapan Peraturan Mahkamah Agung RI Nomor 1 Tahun 2016 di Pengadilan Agama Watampone terhadap sengketa cerai telah berjalan dengan baik namun beberapa segi yang belum terpenuhi, antara lain : Tidak terjadi mediasi pada sekitar $60 \%$ perkara perceraian, karena tergugat tidak hadir di sidang pengadilan. Sulitnya mempertemukan penggugat dan tergugat karena pada umumnya mereka yang mau cerai, persoalannya sudah sangat parah dan sangat sulit lagi didamaikan. Yang selalu melanggar terhadap aturan Pasal 7 ayat 1 dan 2 Perma No. 1 Tahun 2016 adalah pihak tergugat, saat wawancara belum pernah ada penggugat/ pemohon yang melanggar. Oleh karena itu, sanksinya hanya pembebanan biaya mediasi, itupun tidak terjadi karena tidak pernah datang dan penggugat juga tidak keberatan. Kalau pun para pihak hadir dalam mediasi, mereka bertengkar terus dan tidak ada yang mau mengalah, akhirnya dilakukan mediasi secara kaukus, artinya dipanggil satu persatu masuk ke ruang mediasi secara bergantian. Keberhasilan Mediator dalam mendamaikan pihak-pihak yang mempunyai sengketa cerai di Pengadilan Agama

${ }^{18}$ Drs. H. Kamaluddin dkk.Hakim Pengadilan Agama Watampone, Wawancara oleh peneliti di Pengadilan Agama Watampone, 15Agustus 2016.

${ }^{19}$ Drs. H. Amiruddin, M.H.Hakim Pengadilan Agama Watampone, Wawancara oleh peneliti di Pengadilan Agama Watampone, 16Agustus 2016. 
Ekspose volume 16, Nomor 1, Januari - Juni 2017

P-ISSN: 1412-2715, E-ISSN: 2616-4412

Watampone disebabkan oleh karena memang perkaranya sederhana dan didukung oleh mediator yang mempunyai skill dan berpengalaman. Persentase keberhasilan mediasi pada laporan mediasi, sebenarnya yang banyak berhasil di situ adalah sengketa harta bersama sementara sengketa cerainya tidak berhasil (perkara kumulasi cerai dan harta bersama).

\section{Daftar Pustaka}

Abdul Halim, Konstekstualisasi Mediasi Dalam Perdamaian,(www.badilag.net)

Al-Husaini, Imam Taqiyuddin Abu Bakar bin Muhammad. Kifayatul Akhyar. Surabaya: Bina Iman, 1993, Juz 11

Amriani, S.H., M.H., Nurnaningsih. MEDIASI Alternatif Penyelesaian Sengketa Perdata di Pengadilan. Cet. II, Jakarta: PT. Rajagrafindo Persada, 2012.

Anonimous. Buku Komentar Peraturan Mahkamah Agung RI No. 01 Tahun 2008 tentang Pelaksanaan Mediasi di Pengadilan. Dibuat atas kerjasama MARI, Japan International Cooperation Agency (JICA) dan Indonesia Institute for Conflict Transformation (IICT), 2008.

Arto, A. Mukti. Mencari Keadilan (Kritik Dan Solusi Terhadap Praktik Paradilan Perdata di Indonesia). Yogyakarta : Pustaka Pelajar Offset, 2001.

al-Aynayni, Abu Muhammad Mahmud Ibn Ahmad. al-Bidãyah fi Syarh al-hidãyah. Beirut: Dar al-Fikr, t.th.

B. Lewis, E. van Donzel, dkk (ed), Encyclopedia of Islam. Leiden: E.J. Brill, 1990. Jilid IV.

Malik bin as-Sayyid ,Abu Kamal. Shahih Fikih Sunnah. Jakarta: Pustaka Azzam, 2007.

MZ, Muslih. Mediasi:Pengantar Teori dan Praktek, (Semarang: Walisongo Mediation Centre, 2007.

Muhammad Al-Husaini, Imam Taqiyuddin Abu Bakar bin. Kifayatul Akhyar. Surabaya: Bina Iman, 1993.

Nasution, S. Metode Research (Penelitian Imiah). Jakarta: PT. Bumi Aksara. 2003.

Peraturan Mahkamah Agung RI Nomor 1 Tahun 2016 tentang Prosedur Mediasi di Pengadilan.

Peraturan Pemerintah Nomor 9 Tahun 1975 tentangPelaksanaanUndang-Undang No. 1 Tahun 1974 tentangPerkawinan.

Republik Indonesia. Undang-Undang Nomor 48 Tahun 2009 tentang Kekuasaan Kehakiman

Roberts, Marian. Mediation in Family Disputes: Principles and Practice (Third Edition), Hampshire: Ashgate Publishing Ltd, 2008. 
Ekspose volume 16, Nomor 1, Januari - Juni 2017 P-ISSN: 1412-2715, E-ISSN: 2616-4412

Ronal S. Kraybill, Alice Frazer Evans dan Robert A. Evans, Peace Skill, Panduan Mediator terampil Membangun Perdamaian. Yogyakarta: Penerbit Kanisius, 2006.

as-Sayyid, Abu Kamal Malikbin. Shahih Fikih Sunnah. Jakarta: Pustaka Azzam, 2007.

Tim Penyusunan Kamus Pusat Pembinaan dan Pengembangan Bahasa, Kamus Besar Bahasa Indonesia. Jakarta: Departemen Pendidikan dan Kebudayaan, 1988. 